\title{
The Effect of Client Firm's IT Capability on IS Outsourcing Success in Tunisia: The Mediating Role of Relationship Quality
}

\author{
Hanène Trabelsi Ellouze“, Jamil Chaabouni \\ Department of Management, Faculty of Economics and Management, University of Sfax, Sfax, Tunisia \\ Email address: \\ hanenetr@yahoo.fr (H. T. Ellouze), Jamil.Chaabouni@fsegs.rnu.tn (J. Chaabouni) \\ ${ }^{*}$ Corresponding author
}

To cite this article:

Hanène Trabelsi Ellouze, Jamil Chaabouni. The Effect of Client Firm's IT Capability on IS Outsourcing Success in Tunisia: The Mediating Role of Relationship Quality. International Journal of Business and Economics Research. Vol. 8, No. 4, 2019, pp. 170-179.

doi: $10.11648 /$ j.ijber.20190804.12

Received: April 8, 2019; Accepted: May 27, 2019; Published: July 2, 2019

\begin{abstract}
Outsourcing IS services has been on the rise in developed as well as developing countries in the world. Despite the IS outsourcing trends seen over the past several years, some outsourcing experiences are failing. One frequently cited reason is the lack of previous research to address the effect of the client firms' IT capabilities on the IS outsourcing success. In order to achieve the IS outsourcing success, firms hope also to have a flexible relationship with their external providers. The quality of the relationship between the client firm and the external provider may therefore be a key element of successful outsourcing. The objective of this research is firstly to identify the impact of the client firm's IT capability on IS outsourcing success and secondly to clarify the role of the relationship quality between the client firm and the service providers in IS outsourcing success. To achieve this objective, a model is developed based on the literature review. Quantitative method based on a questionnaire survey is adopted for this research. We are interesting in the Tunisian banking sector characterized by a growing demand for the IS outsourcing. Data collected are analyzed by Structural Equation Modelling using PLS (Partial Least Squares) technique to test the research hypotheses. The results indicate that IT capability has no effect on IS outsourcing success and among the dimensions of the relationship quality, only the communication quality has a direct effect on outsourcing success.
\end{abstract}

Keywords: IS Outsourcing Success, IT Capability, Relationship Quality, Tunisian Banking Sector, PLS

\section{Introduction}

In recent years, the growth of IS outsourcing has been phenomenal [1-3], concerning mainly the European and American markets. The growth of the outsourcing practice concerns also Tunisian firms. Indeed, with the opening of Tunisia on the external market and in order to be competitive, Tunisian firms are called to refocus on their core business and to outsource certain activities including information systems. Tunisia has been committed for nearly two decades in a policy of valorization of information technologies (IT). The dynamics of the Tunisian market is also evidenced by the classification of the report of the World Economic Forum on information and communication technologies (ICT) which ranks Tunisia in 2010 in first place in the Arab world and in
Africa in the field of ICT and in first position in 2014 in the Maghreb region [4]. Currently, the ministry launches the new strategy "Digital Tunisia 2020" which aims to "make Tunisia an international reference in the field and make ICT an important lever for socio-economic development" [5]. This strategy is structured around a number of areas including infrastructure (4G, cloud computing), e-business (health, tourism, education,...), e-gov (e-government) and Smart Tunisia (offshoring and co-production). The IS outsourcing practice presents for professionals a major opportunity. However, despite the spread of this practice, some outsourcing experiences fail [6-7]. Indeed, the expected benefits are not always achieved after outsourcing [8-9]. A plausible explanation for this failure is that, to date, researchers have not been able to model all the factors that 
could influence IS outsourcing success [9-10]. In the context of IS outsourcing, the client firms need specific capabilities to engage successfully with service providers [11]. Each organization has a fundamentally different predisposition to exploit resources, evaluate their value, assimilate them, and apply them to final goods. This is termed the firm's "capabilities" [12]. Among these capabilities, the client firm's IT capability deserves to be studied. Having IT capability not only allows organizations to outpace their competitors, but also becomes one of the critical resources for 21 st century [3]. IT capability is seen as an assembly of hardware, software, services, management practices, technologies, and management skills [13]. In addition to the ability of the client firm to outsource its IS activities successfully, the relationship quality is also an important factor as it can influence the success or the failure of such practice. Indeed, in order to achieve the outsourcing success, organizations also hope to have a flexible relationship with their external providers $[8,14,15]$. The relationship quality between the client firm and the external provider can therefore be a key element of successful outsourcing [16-17]. The purpose of this paper is to study the impact of the client firm's IT capability on IS outsourcing success insofar as client's capabilities have an impact on the relationship quality between the client and the service provider and thus on IS outsourcing success.

\section{Theoretical Framework}

The theoretical framework of this paper has been organized into three sections: the following section presents IS outsourcing and IS outsourcing success, the second section reviews IT capability and the third section focuses on the relationship quality between client firms and service providers as a mediating variable between IT capability and IS outsourcing success.

\subsection{IS Outsourcing and IS Outsourcing Success}

IS outsourcing is defined as a strategic decision that requires external IS activities needed to produce goods or services. This decision requires the use of agreements or contracts, a client firm's capability to undertake these activities and a close relationship with the service provider $[18,10,19]$. IS outsourcing activities that have been of considerable interest in recent years are software development [20-21]. Outsourcing of software development activities is defined as a situation where a client firm entrusts all or part of its software development activities to another company (a service provider), which provides agreed services for a fee [22]. IS outsourcing success is defined in terms of project completion over time within budget, improved IS quality and knowledge transfer [23]. The success of the project is focused on the criteria of the software development process "on time", "budget compliance" and "response to needs" of the client firm. A project could succeed totally or partially or fail completely. Total success refers to the achievement of all the intended objectives of a project. Partial success on the other hand is characterized by project completion with certain objectives being unachieved. If a project fails to meet all or the majority of its intended purposes, then it can be considered as total failure [23].

User satisfaction is often used as an overall measure of outsourcing success [16]. It allows respondents to express their appreciation of the outsourcing of their IS activities on the basis of the criteria perceived to be the most relevant. Satisfaction can be considered as a positive state resulting from all aspects of IS outsourcing [24]. It is defined as the level of adjustment between the expectations of the client firm and the results of outsourcing [25].

\subsection{IT Capability}

The IT capability literature has its origins in resourcebased theory. According to this theory, the relationship between competitive advantage and firm resources is considered business-specific, rare and difficult to be emulated by competitors [12]. IT capability can be viewed from two perspectives. According to the first perspective, it refers to managerial capabilities [26]. According to the second perspective, it refers to technical capabilities [27, 28, 29]. In the context of IS outsourcing, Mata et al.'s finding [30] indicated that managerial IT capability was only one influential factor that providing sustained competitive advantage. In addition, [31] emphasize that only technical and managerial IT capabilities are important for IS outsourcing success [8]. In the same sense, [31] indicate that IT-related human capability is important in the context of IS outsourcing. The two IT capabilities identified in the literature consulted $[25,8,31]$, in this case technical capability and IT managerial capability are taken into account in the context of this research.

\subsubsection{Technical Capability}

Technical capability is a combination of technical skills and know-how developed over time that enables a company to acquire, deploy and leverage IT investments in search for business strategies [32]. According to [8], technical capabilities refer to technical knowledge and skills needed to develop applications. Technical skill is a heterogeneous enterprise capability, developed over time, composed of interdependent routines [12]. Technical skills can range from a simple understanding of IS functionality to the ability to improve and modify the content of a specific application [33]. The ways of apprehending and exploiting a new IS application are therefore conditioned by the technical skills that IT managers are able to develop.

\subsubsection{IT Managerial Capability}

In addition to technical capabilities, the client firm needs the ability to plan, organize, lead and control the activities necessary for it to succeed. In other words, it needs to possess certain managerial skills in order to successfully outsource its IS activities [24]. In the case of IT, managerial skills include management's ability to conceive of, develop, 
and exploit IT applications to support and enhance other business functions [30]. According to [30], IT managerial capability refers to:

- The ability of IT managers to understand and appreciate the business needs of other functional managers

- The ability to work with these functional managers to develop appropriate IT applications

- The ability to coordinate IT activities in ways that support other functional managers

- The ability to anticipate the future IT needs of functional managers

Managerial IT skills enable firms to manage the market risks associated with investing in IT. Firms can acquire technical IT skills by hiring programmers and analysts. They then use their managerial IT skills to help programmers and analysts fit into an organization's culture, understand its policies and procedures, and learn to work with other business functional areas on IT-related projects.

\subsection{Relationship Quality Between Client Firm and Service Providers}

The relationship quality refers to the client's perception of how the relationship fulfills its expectations, predictions, goals, and desires [34]. It gives the client a global impression of the entire relationship, including the different transactions. The relationship quality affects positively both the development and the maintenance of the relationship between the client and the service providers [35]. The process of developing the relationship quality is based on face-to-face interaction between the managers of the service provider and that of the client firms. IS research identifies several dimensions of the relationship quality in the context of IS outsourcing as well as the link between the relationship quality and IS outsourcing success [16, 1, 36, 14]. The literature [8-36] indicates that communication quality and knowledge transfer are the dimensions of the relationship quality that most influence the IS outsourcing success.

\subsubsection{Communication Quality}

Communication is the formal and informal sharing of relevant and periodic information between partners [37]. Communication plays an important role in an inter-organizational relationship. The communication quality is apprehended by the punctuality, relevance, accuracy and credibility of communication [38]. According to the theory of social exchange, effective communication is essential in achieving the desired goals. Intensive communication keeps partners better informed and makes them more willing to maintain the relationship [39]. IS outsourcing partners are expected to have a flexible project team that can communicate project objectives and costs. For this condition to be met, the team conducts periodic meetings to meet the needs of each stage of the project. The service provider and the client firm need to communicate clearly the threshold of goals in advance of the project and throughout its duration.

\subsubsection{Knowledge Transfer}

Knowledge-based theory views the firm as a dynamic, evolving, and quasi-autonomous system of production and application of knowledge [40]. This perspective argues that knowledge is the main resource of firms and that production requires the integration of a wide range of knowledge [41]. This knowledge is a crucial factor in the context of IS outsourcing. Firms outsource activities outside their core competencies [11]. As a result, they acquire external knowledge that is integrated into their routines and processes. This transfer of knowledge between the client firms and their service providers is two-way: on the one hand, the knowledge is transferred from the provider to the client firm and on the other hand, from the client firm to the provider. In both cases, the goal is to increase knowledge sharing through these knowledge transfer processes. The literature qualifies differently the moment of the transfer of knowledge. Indeed, some researchers adopt the simple approach of an exchange by defining the transfer of knowledge as explicit or tacit knowledge exchange activities between two agents, in which one agent receives and applies knowledge provided by another. Agents can be an individual, a team/department or an organization [42]. Other researchers focus on the resulting changes to the container.

\section{Research Model and Hypotheses}

The research model is based on determinism of relations between the dependent variables and the independent variables to reinforce the theoretical foundations developed in the previous section. These relations reflect the research hypotheses that validate the causal structure of the model.

\subsection{Impact of IT Capability on IS Outsourcing Success}

The study of the impact of IT capability on IS outsourcing success is inspired by the work of [24] and [8] who, through empirical studies, show the indirect link between this capability and IS outsourcing success. However, the study of technical capability reveals a possible direct impact. Two dimensions relate to IT capability: technical capability and IT managerial capability.

\subsubsection{Indirect Impact of Technical Capability on the IS Outsourcing Success}

The rapid evolution of the environment forces firms to develop various technical skills. Although by outsourcing its IS, the client firm could reduce the burden of maintaining such IT capability, the technical capability of IT managers could actually be a lever of competence for the provider [11]. The technical expertise of IT managers can contribute to the performance of the service provider in four ways: clients are able to identify competent providers, monitor providers' activities more clearly, provide increased assistance to service providers and attract the best providers [33]. First, clients who understand the basics of the development and production process will be better able to identify the most appropriate providers. Clients with technical skills are able to screen and select providers because they can interpret their offers, comparing them according to both technical 
characteristics and price [43]. Secondly, clients with high technical expertise can understand the activities of their providers so that they can track their performance more effectively to ensure that they meet their needs. Third, clients with high technical skills can more easily communicate technical details with providers. Expertise gives clients an evaluation capability by which they are better able to designate metrics and quality levels that are stringent and achievable. Thus, they can contribute to improving the skills of their providers. Fourth, the technical expertise of clients can attract more providers.

H1: The technical capability of IT managers influences positively IS outsourcing success through the relationship quality with the service provider.

The relationship quality has two dimensions: communication quality and knowledge transfer. The impact of technical capability on the outsourcing success is carried out through each of these dimensions.

1. In their study of the impact of a firm's capability on outsourcing success, [8] state that the technical knowledge of IT personnel makes it easier for the client firm to communicate technical details with the service providers. Expertise provides clients an ability to define and to evaluate strict and achievable metrics and quality levels [44].

H1.1: The technical capability of IT managers influences positively IS outsourcing success through communication quality with the service provider.

2. The knowledge and technical skills of IT managers can motivate providers to share information with client firm [45]. Technical skills allows IT managers to participate and to be involved in IS projects. In particular, knowledge transfer is the most important knowledge process in an IT outsourcing relationship [46]. The more capabilities and technical skills clients have, the more involved they become by participating with the project team, leading to a more efficient knowledge transfer [47]. The knowledge and information transfer between client firms and their service providers leads to learning new routines on how to manage IT [31].

H1.2: The technical capability of IT managers influences positively IS outsourcing success through the knowledge transfer of the service provider to the client firm.

\subsubsection{Direct Impact of Technical Capability on the IS Outsourcing Success}

The technical skills of the service provider are the most important factor in the outsourcing success [48]. [48] also claim that the technical capability of the client firm has also a positive impact on IS outsourcing success. Similarly, IT managers' technical understanding mitigates the risks associated with IS applications outsourcing and thus ensures its success [49]. This understanding is necessary for the client firm to use its applications effectively in order to achieve the expected objectives.

H2: The technical capability of IT managers influences positively and directly IS outsourcing success.

\subsubsection{Indirect Impact of IT Managerial Capability on the IS Outsourcing Success}

The managerial capability of the IT managers is necessary to understand and solve business problems that may appear in the client firm. IT managers are not able to be business experts, but to a certain extent they are required to understand the company's goals, language, and processes [11]. In the IS outsourcing context, the managerial capability of IT managers is associated with a high level of the interaction process between the client firm and the service providers [45]. This ability can guide the service provider's effort toward the performance of several business processes [8].

H3: The managerial capability of IT managers influences positively IS outsourcing success through the relationship quality with the service provider.

IT managerial capability depends on other interpersonal relationships [30]. The impact of IT managerial capability is carried out through each of the dimensions of the relationship quality:

1. The managerial capability of IT managers helps service providers to integrate into the corporate culture, understand its policies and procedures, and learn how to work on IT related projects. This can be achieved by facilitating communication within the firm and improving problem-solving capabilities [8].

H3.1: The managerial capability of IT managers influences positively IS outsourcing success through communication quality with the service provider.

2. A thorough understanding of business needs and requirements by IT managers can encourage the service provider to engage actively in communication and knowledge-sharing activities with the client firm [8] and thus ensure IS outsourcing success.

H3.2: The managerial capability of IT managers influences positively IS outsourcing success by transferring knowledge from the service provider to the client firm.

\subsection{Impact of the Relationship Quality on the IS Outsourcing Success}

The relationship quality is an important factor for client firm [50]. Indeed, the difficulties that some client firms may encounter with their service providers require taking into account the relationship between these two parties. Many outsourcing operations fail and fall short of the expectations of client firms [51]. This is due to a failure in the relationship between the two parties. This shows that establishing reliable relationships can help ensure the success of outsourcing projects and foster long-term relationships between clients and service providers [16]. Many studies highlight the importance of the relationship quality for IS outsourcing success $[8,14,15]$.

H4: The relationship quality influences directly and positively IS outsourcing success.

The relationship quality has two dimensions: communication quality and knowledge transfer.

1. The literature on the outsourcing risks indicates the 
importance of the communication quality between the client firm and the service provider and considers it as an essential requirement for outsourcing success in terms of meeting the expectations of time, cost and quality [52].

H4.1: Communication quality influences directly and positively IS outsourcing success.

2. Recently, IS outsourcing research focuses on the transfer of knowledge between service providers and client firms and postulates that effective knowledge transfer is essential to meet the perceived needs of client firms and to achieve IS outsourcing success [17, $36,53]$.

H4.2: Knowledge transfer from the service provider to the client firm influences directly and positively IS outsourcing success.

The research model is presented based on the previous developments. This model has three levels and incorporates concepts related to IT capability, the relationship quality between the client firm and the service provider and IS outsourcing success (Figure 1).

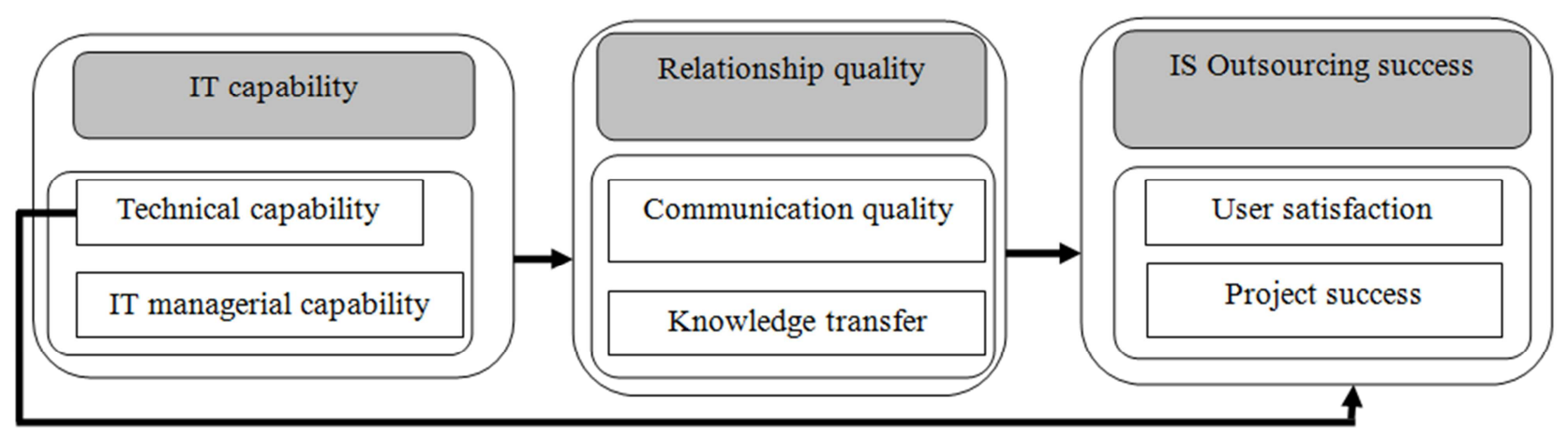

Figure 1. Research model.

\section{Research Methodology}

This research was carried out within the Tunisian banking sector. The choice of the banking sector is justified by the banking sector's demand for IS outsourcing, which is growing steadily around the world [54]. This is also the case for Tunisian banks which, faced with an increasingly clients demanding, are obliged to offer information on time and with regular access. Recently, new advances in IT allow banks to use outsourcing as a way to reduce costs and focus on core skills. Indeed, the increasing pressure for banks to provide high quality services to satisfy their clients requires them to use a complex and diversified set of technologies to manage their business. IS outsourcing allows banks to support their strategic initiatives through rapid and cost-effective access to new technologies.

\subsection{Measures}

The survey instrument is developed by considering prior studies with similar concepts to ours. Each of the multi-items was measured using a six-point Likert scale with items ranging from "strongly disagree" to "strongly agree". The even number of positions (6) is chosen t'o prevent respondents from falling back on the average position." The questionnaire is constructed in three stages: the development of the initial version, the pre-test and the elaboration of the final version of the questionnaire. However, modifications are made to adapt the existing items to the needs of our investigation (Table 1). Two variables are introduced to investigate a firm's IS outsourcing success: IT capability (technical and IT managerial) and relationship quality.
Table 1. Summary table of measurement scales of research variables.

\begin{tabular}{ll}
\hline Latent variables & Sources of measurement scales \\
\hline Technical capability & {$[55]$} \\
IT managerial capability & {$[8]$} \\
Communication quality & {$[56]$} \\
Knowledge transfer & {$[31]$} \\
User satisfaction & {$[24]$} \\
Project success & {$[57]$} \\
\hline
\end{tabular}

\subsection{Data Collection}

The survey took place in Tunis at the headquarters of the banks where the IT departments reside. The mother population is the list of banks developed by the Tunisian Professional Association of Banks and Financial Institutions (A. P. T. B. E. F). According to the website of the association, the banking sector has 22 banks. In line with the objectives of this research, the study population consists of banks that outsource their software development activities. Of the 22 banks contacted, 14 accepted to participate in the survey, a rate of $63.63 \%$. The sample was made through a reasoned choice. In a first step, we contacted the directors in charge of the IS department of 14 bank offices to answer the questionnaire. Then, these managers guided us to the IT managers (IS directors, outsourcing project team leader, outsourcing project team member) involved in the software development outsourcing project. In a second step, the questionnaire was sent to IS managers involved in the software development outsourcing project. These are considered as key informants of aspects that affect information systems of firms. Of the approximately 120 IT managers solicited for the study, only 85 responded, representing a return rate of around $70.83 \%$. Out of the 
returned questionnaires, 5 were discarded due to incompleteness. Thus, 80 questionnaires could be used in our final analysis.

\section{Data Analysis and Results}

\subsection{Analysis of the Psychometric Properties of Measurement Scales}

The analysis of psychometric properties is generally based on two stages, the first is exploratory (EAF), the second is confirmatory (CFA) to assess the reliability and validity of measurement scales. Table 2 summarizes the results of the exploratory factor analysis:

Table 2. Results of the exploratory factor analysis.

\begin{tabular}{lll}
\hline Constructs & Dimensions & Cronbach's Alpha \\
\hline \multirow{2}{*}{ Technical capability } & IT knowledge & 0,852 \\
IT managerial capability & IT Experience & 0,762 \\
Knowledge transfer & - & 0,771 \\
Communication quality & - & 0,658 \\
User satisfaction & - & 0,875 \\
& Product success & 0,928 \\
Project success & Project management & 0,849 \\
& success & 0,885 \\
\hline
\end{tabular}

\subsection{Confirmation and Validation of Measurement Scales: Confirmatory Factorial Analysis (CFA)}

Confirmatory factor analysis (CFA) makes it possible to assess the reliability and the validity of the different constructs. The composite reliability indices (CR) obtained vary between 0.80 and 0.924 , while the average variance extracted (AVE) oscillate between 0.528 and 0.709 , which exceeds for the first the required threshold of 0.7 [58] and for the latter the required threshold of 0.5 [59]. The convergent validity of the model is thus ensured. Discriminant validity is appreciated by examining the factorial contributions (loadings) of the items to their respective theoretical constructs. For each construct, the factorial contributions are greater than the factorial contributions crossed between each item and the other constructs. The discriminant validity is verified.

\section{Evaluation of the Structural Model}

The structural relations is estimated between the constructs by carrying out bootstrapping analyzes on the sample. However, a fundamental step to make before interpreting model estimation results is to check the overall quality of the model. The structural model is evaluated on the basis of the predictive relevance of the latent variables. The $\mathrm{R}^{2}$ determination coefficient determined by the SmartPLS software is greater than 0.1 and the Stone-Geisser $\mathrm{Q}^{2}$ redundancy coefficient is positive for each of the dependent variables [60]. The model therefore has predictive validity.

\subsection{Direct Effects Between the Research Variables}

The significance of the relations between the variables in the model is estimated by examining the coefficients $\beta$ (path coefficients) and the $\mathrm{T}$ values (T-values) obtained after the Bootstrapping analyzes $(n=80,500$ iterations $)$. The test of the structural links between the variables is based on the Student t-test. According to the recommendations of [61], the value of $t$ must respect a minimum threshold of 1.96 .

Table 3. Verification of direct links between variables.

\begin{tabular}{llll}
\hline & $\begin{array}{l}\text { Coefficients } \boldsymbol{\beta} \\
(\boldsymbol{P a h} \text { coefficients })\end{array}$ & $\begin{array}{l}\text { Test T } \\
(\boldsymbol{T} \text { - values })\end{array}$ & Results \\
\hline ITKNO -> OUTSUC & 0,179 & 1,371 & Reject \\
ITEXP -> OUTSUC & 0,063 & 0,421 & Reject \\
COMQUAL -> OUTSUC & 0,365 & 2,909 & Support \\
KNOTRA -> OUTSUC & 0,090 & 0,657 & Reject \\
\hline
\end{tabular}

Test $\mathrm{t}$ : significant if $\mathrm{t}>1.96$ in absolute value

According to this table, no direct effect between technical capability and "IS outsourcing success" is confirmed. The effects of "IT Knowledge" $(\beta=0.179, \mathrm{t}=1.371)$ and "IT Experience" $(\beta=0.063, t=0.421)$ are rejected $(t<1.96)$. Among the effects of the dimensions of the relationship quality exerted on IS outsourcing success, only the effect of communication quality $(\beta=0.365, \mathrm{t}=2.909)$ is verified. The effect of knowledge transfer is not verified $(t=0.657)$.

\subsection{The Indirect Effects Between the Research Variables}

In addition to the direct effects produced by the variables studied, the model reveals indirect links between these variables. The relationship quality is a mediating variable that transmitst totally or partially, the impact of IT capability on IS outsourcing success.

Table 4. Verification of mediation links.

\begin{tabular}{llll}
\hline & Path coefficient $(\boldsymbol{\beta})$ & T-values & Results \\
\hline ITKNO -> OUTSUC & $-0,023$ & 0,213 & Reject \\
ITEXP -> OUTSUC & 0,002 & 0,020 & Reject \\
CAPMG -> OUTSUC & 0,046 & 0,499 & Reject \\
\hline
\end{tabular}

Test $\mathrm{t}$ : significant if $\mathrm{t}>1.96$ in absolute value

From this table, we note that there is not significant mediating relationship between IT capability and IS outsourcing success through the relationship quality.

\section{Discussion and Implications}

Field data don't confirm the direct effect of technical capability on IS outsourcing success. This result contradicts a large body of literature [62-63]. Many firms are motivated to outsource their IS services in order to access higher capabilities of the service provider but the result of outsourcing will be better when both parties, the client firm and the service provider have a high level of technical capabilities [63]. Other researchers report that the client firm's technical capability is essential to evaluate the IS outsourcing process [62]. On the other hand, [64] argues that IS outsourcing allows client firms to focus on the core of their business as they obtain the necessary IT skills from the 
provider. The IT expertise of the service provider appears to be a critical factor in the success of the partnership. Similarly, other researches confirm the existence of a non-significant link between technical capabilities and Information systems outsourcing success [45, 8]. The plausible reason for rejecting this assumption is that in most IT projects, the competence of the service providers and more specifically their technical experience and IT knowledge, may be sufficient. Therefore, less attention is paid to the client firm's technical capability since in the long term the service provider could ensure roles that should have returned to the client firm. This substitution of the provider to the client firm is not risk-free because it leaves the doors open to opportunistic behaviors of the service provider. Similarly, no significant indirect link is found either for IT knowledge or IT experience and IS outsourcing success via relationship quality (respectively $\mathrm{t}=0.213$ and $\mathrm{t}=0.020$ ). This result can be explained by the fact that if IT managers have technical knowledge and experience, they have difficulties in communicating and coordinating technical issues with the service provider since the latter has more information than the IT managers of the client firm. The tacit knowledge transfer is the more intense as the partners are in strong interaction [31]. Thus, an active cooperative learning process facilitates the acquisition and transfer of knowledge. In addition, another explanation for this result may be due to the fact that this research is conducted with the IT managers of the bank, it would be more important to integrate the point of view of service providers to provide a better understanding of the knowledge transfer in a dyadic relationship. Regarding the IT managerial capability, the results show that there is not a significant indirect link between the IT managerial capability and IS outsourcing success via the relationship quality of $(\mathrm{t}=0.499)$. By adopting the perspective of the service provider, it is important that the IT skills of service providers are a prerequisite for engaging with the client firm, but it is their managerial skills that distinguish them from their competitors and allow them to succeed in both the short and the long term [65]. In the same way, [24] states that the capabilities of the service provider, including their managerial capability, are important and have an effect on the IS outsourcing success through the relationship between the parties. On the other hand, the capabilities of the client firm have no significant effect on the relationship. Therefore, we can deduce that it is rather the service providers that must have managerial capability in order to engage actively with the client firm and thus ensure IS outsourcing success. This result can be explained by the fact that, from the point of view of bank, it is rather the service provider who is able to carry out an IT plan in line with the bank's strategy and to constantly update the IT strategy depending on changes in the environment. Since the bank pays the service provider for its expertise in these areas, this capability allows the provider to easily communicate details of the bank's policy and procedures and thus ensure IS outsourcing success. The results also indicate that among the effects of the dimensions of the relationship quality exerted on IS outsourcing success, only the effect of communication quality $(\beta=0.365, \mathrm{t}=2.909)$ is verified. This result confirms several works $[16,24,66]$ according to which the communication quality leads to IS outsourcing success. Indeed, frequent and effective communication can contribute firstly to a better planning of the works. More specifically, by communicating frequently and effectively with IT managers, the service provider can get a clear idea of the needs of banks and the nature and timing of the resources that will be needed. Secondly, frequent and effective communication can help the service provider to keep up with the changing priorities of banks and help align the development of resources to meet their shortterm needs. This is particularly important in the context of software development, where the need to "fight" day-to-day to fix software bugs and unexpected implementation problems are able to be coordinated through work improvement. Thirdly, frequent and effective communication can help the service provider to narrow the gap between the current state of the project and the desired project trajectory of banks, which, constantly informed of the progress of the software development process, can provide quick feedback and helpful contributions in later stages of development.

\section{Conclusion}

As IS outsourcing becomes a commonly accepted and growing practice, its scope and extent are continuously expanding. While the literature on outsourcing reveals the social and psychological aspects of an outsourcing relationship, the managerial need to exploit these relationship attributes has been little explored. The relationship quality is identified as a key intervening variable that affects IT capability. The results indicate that the IT capability of the IT managers of banks (technical capability and IT managerial capability) doesn't affect IS outsourcing success. This result can be explained by the fact that this IT capability generally evolves over long periods through the accumulation of experience. Also, for a long-term prior commitment of a service provider with a client firm could let the provider takes over the roles of the client related to its technical capability. Similarly, the results indicate that the relationship quality is not a mediator between IT capability and IS outsourcing success. One way of interpreting this is that the IT managers of banks consider that the service provider must bear the main burden of providing both the agreed IT services and managing the relationship. While the main concern of IT managers is to focus on the core business of the bank. This is not surprising, since the banks consider that they pay the service provider for its expertise in these areas. The results also show that among the dimensions of relationship quality, only the communication quality has a direct effect on IS outsourcing success. Through frequent and effective communication, the service provider can have a clear idea of the bank's needs and the nature and timing of the resources that will be needed. Concerning the theoretical contributions, this research proposes a research model following a systemic approach of the evaluation of IS 
outsourcing success. The designed model postulates the examination of direct and indirect relationships between three interdependent levels of analysis (IT capability, the relationship quality and IS outsourcing success). At the managerial level, this research has revealed the importance of the relationship quality to enhance the communication quality between the bank's IT managers and service providers. Indeed, the communication quality is essential to IS outsourcing success. Two committees ensure the proper conduct of the project. On the one hand, a monitoring committee, whose members are the IT managers, is held on a regular basis. The purpose of this committee is to detect problems if they exist and to monitor the progress of the project. On the other hand, a steering committee takes place periodically. The goal of the steering committee is to make strategic decisions about the project. Therefore, the service provider and the bank need to communicate clearly the threshold of goals in advance of the project and throughout its duration. As a result, a flexible and responsible project team is required to conduct periodic meetings to satisfy the needs of each stage of the project. This research has certain limitations. Firstly, the size of the sample of 80 IT managers in 14 Tunisian bank offices doesn't allow generalization of the research results and thus limits the external validity of the research. Secondly, this research is of an instant nature that doesn't consider the feedback effect between the relationship quality and IS outsourcing success over time. Future research could include other organizational capabilities in the research model such as the service provider management capability.

\section{References}

[1] Qi, C. and Chau, P. Y. K. (2013), "Investigating the roles of interpersonal and interorganizational trust in IT outsourcing success", Information Technology \& People, Vol. 26, $\mathrm{N}^{\circ} 2$, pp. 120-145.

[2] Gunasekaran, A., Irani, Z., Choy, K. L. and Filippi, L. (2015), "Performance Measures and Metrics in Outsourcing Decisions: A Review for Research and Applications", International Journal of Production Economics, Vol. 161, pp. $153-166$.

[3] Kiteme, S. L. and Wausi, A. N. (2019) "The Influence of Firms' Capability on Delivery of Quality Outsourced ICT Services in Kenya: A Case Study of a Public Institution", International Journal of Recent Innovations in Academic Research, Vol. 3, N², pp. 103-113.

[4] Jankari, R. (2014), "Les technologies de l'information au Maroc, en Algérie et en Tunisie Vers une filière euromaghrébine des TIC ?", Études \& analyses, Institut de prospective économique du monde méditerranéen.

[5] Msaed, W. (2016), "L'économie numérique en Tunisie: Les promesses et les freins", Kapitalis, http://kapitalis.com/tunisie/2016/03/28/leconomie-numeriqueen-tunisie-les-promesses-et-les-freins/?upm_export=pdf

[6] Prado, E. P. V., De Souza, C. A., Takaoka, H. and Reinhard, N. (2009), "Contracting outsourced Information Technology services in Brazil", Journal of Global Information Technology Management, Vol. 12, N4, pp. 52-71.

[7] Huber, T. L., Fisher, T. A., Kirsch, L. and Dibbern, J. (2014), "Explaining emergence and consequences of specific formal controls in IS outsourcing: a process-view", 47th Hawaii International Conference in Information Systems, 6-9 Janvier, Waikoloa, HI.

[8] Han, H.-S., Lee, J.-N. and Seo, Y.-W. (2008), "Analyzing the impact of a firm's capability on outsourcing success: A process perspective", Information and Management, Vol. 45, pp. 31-42.

[9] Kim, H. J., Shin, B. and Lee, H. (2013), "The mediating role of psychological contract breach in IS outsourcing: inter-firm governance perspective", European Journal of Information Systems, Vol. 22, pp. 529-547.

[10] Schwarz, C. (2014), "Toward an understanding of the nature and conceptualization of outsourcing success", Information and Management, Vol. 51, $\mathrm{N}^{\circ} 1$, pp. 152-164.

[11] Feeny, D. F. and Willcocks, L. P. (1998), "Core IS Capabilities for Exploiting Information Technology", Sloan Management Review, Vol. 39, N³, pp. 354-367.

[12] Barney, J. B. (1991), "Firm resources and sustained competitive advantage", Journal of Management, Vol. 17, $\mathrm{N}^{\circ} 1$, pp. 99-120.

[13] Wang, L. and Alam, P. (2007), "Information technology capability: firm valuation, earnings uncertainty and forecast accuracy", Journal of Information Systems, Vol. 21, N², pp. $27-49$

[14] Swar, B., Moon, J., Oh, J. and Rhee, C. (2012), "Determinants of relationship quality for IS/IT outsourcing success in public sector", Information Systems Frontiers, Vol. 14, N², pp. 457 475.

[15] Cetinkaya, A. S., Ergul, M. and Uysal, M. (2014), "Quality relationship on information technology outsourcing for organizational success in hospitality industry", Journal of Hospitality and Tourism Technology, Vol. 5, N³, pp. 229244.

[16] Lee, J. N. and Kim, Y. G. (1999), "Effect of partnership quality on is outsourcing: conceptual framework and empirical validation", Journal of Management Information Systems, Vol. $15, \mathrm{~N}^{\circ} 4$, pp. 29-61.

[17] Lee, J. N. (2001), "The impact of knowledge sharing, organizational capability and partnership quality on IS outsourcing success", Information and Management, Vol. 38, pp. 323-335.

[18] Espino-Rodriguez, T. and Padron-Robaina, V. (2006), "A review of outsourcing from the resource-based view of the firm" International Journal of Management Reviews, Vol. 8, $\mathrm{N}^{\circ} 1$, pp. 49-70.

[19] Chou, S. W., Techatassanasoontorn, A. A. and Hung, I. H. (2015), "Understanding commitment in business process outsourcing relationships", Information and Management, Vol. 52, pp. 30-43.

[20] Wanjin, H., Luchuan, L. and Yu, C. (2007), "Software Outsourcing in Beijing: Basics, Trends and Implications," Proceedings of IEEE International Conference on Systems, Man and Cybernetics, pp. 3235-3239. 
[21] Rustagi, S., King, W. R., and Kirsch, L. J. (2008), "Predictors of Formal Control Usage in It Outsourcing Partnerships," Information Systems Research, Vol. 19, N², pp. 126-143.

[22] Kern, T. and Willcocks, L. (2000), "Exploring information technology outsourcing relationships: theory and practice", Journal of Strategic Information Systems, Vol. 9, $\mathrm{N}^{\circ} 4$, pp. 321-350.

[23] Waheed, U. and Molla, A. (2004), "Information Systems Outsourcing Success: A Client-Service Provider Gap Analysis in Pakistan", Journal of Information Technology Management, Vol. 15, pp. 1-13.

[24] Goles, T. (2001), The Impact of the Client/Vendor Relationship on Outsourcing Success, Thèse de doctorat, University of Houston, Houston, TX, 230p.

[25] Lee, J. N. and Kim, Y. G. (2003), "Exploring a Casual Model for the Understanding of Outsourcing Partnership", Proceedings of the 36th Hawaii International Conference on System Science.

[26] Sambamurthy, V. and Zmud, R. W. (1992), Managing IT for success: The Empowering Business Partnership, Morristown, NJ: Financial Executives Research Foundation.

[27] Teo, T. S. H. and King, W. R. (1997),"An Integration of Business Planning and Information Systems Planning: An Evolutionary Integration perspective", Journal of Management Information Systems, Vol. 1, N${ }^{\circ}$, pp. 185-214.

[28] Sabherwal, R. (1999), "The relationship between information system planning sophistication and information system success: An empirical assessment", Decision Sciences, Vol. $30, \mathrm{~N}^{\circ} 1$, pp. 137-68.

[29] Byrd, T. A. and Turner, D. E. (2000), "Measuring the flexibility of information technology infrastructure: Exploratory analysis of a construct", Journal of Management Information Systems, Vol. 17, N${ }^{\circ}$, pp. 167-208.

[30] Mata, F. J., Fuerst, W. L. and Barney, J. B. (1995), "Information technology and sustained competitive advantage: a resource-based analysis", MIS Quarterly, Vol. 19, N4, pp. 487-505.

[31] Park, J. Y., Im, K. S. and Kim, J. S. (2011), "The role of IT human capability in the knowledge transfer process in IT outsourcing context", Information \& Management, Vol. 48, $\mathrm{N}^{\circ}$, pp. 53-61.

[32] Lacity, M. C. and Willcocks, L. P. (2001), Global IT Outsourcing: In Search of Business Advantage, Chichester: Wiley.

[33] Parmigiani, A. and Mitchell, W. (2010), "The hollow corporation revisited: Can governance mechanisms substitute for technical expertise in managing buyer-supplier relationships", European Management Review, Vol. 7, pp. 4670.

[34] Jarvelin, A. and Lehtinen, U. (1996), "Relationship quality in business-to-business service context", In Edvardsson. B. B. Johnston, S. W. and Scheuing, E. E. (Eds), QUIS5 Advancing Service Quality: A Global Perspective, Warwich Printing Company Ltd, pp. 243-254.

[35] Akrout, H. (2014), "Relationship Quality in Cross-Border Exchanges: A Temporal Perspective", Journal of Business-toBusiness Marketing, Vol. 21, N³, pp. 145-169.
[36] Blumenberg, S., Beimborn, D., Martin, S. F., Brodnik, B., Gunne, C. and Wendt, S. (2009), "Determinants of Outsourcing Success in the Financial Industry: The Impact of Importance", Proceedings of the 42nd Hawaii International Conference on System Sciences, pp. 1-10.

[37] Anderson, J. C and Narus, J. A. (1984), "A Model of Distributor Firm and Manufacturer Firm Working Partnerships", Journal of Marketing, Vol. 48, $\mathrm{N}^{\circ}$ 1, pp 62-74.

[38] Fleming, R. and Low, G. (2007), "Information Systems Outsourcing Relationship Model", Australasian Journal of Information Systems, Vol. 14, º3, pp. 95-112.

[39] Mirani, R. (2007), "Procedural coordination and offshored software tasks: lessons from two case studies", Information and Management, Vol. 44, №2, pp. 216-230.

[40] Spender, J. C. (1996), "Organizational knowledge, learning and memory: three concepts in search of a theory", Journal of Organizational Change Management, Vol.9, pp. 163-79.

[41] Grant, R. M. (1996), "Prospering in dynamically-competitive environments: Organizational capability as knowledge integration", Organization Science, Vol. 7, N4, pp. 375-387.

[42] Joshi, K., Sarker, S. and Sarker, S. (2007), "Knowledge transfer within information systems development teams: examining the role of knowledge source attributes", Decision Support Systems, Vol. 43, N², pp. 322-335.

[43] Petersen, K. J., Handfield, R. B. and Ragatz, G. L. (2005), "Supplier integration into new product development: Coordinating product, process and supply chain design", Journal of Operations Management, Vol. 23, pp. 371-388.

[44] Tiwana, A. and Keil, M. (2007), "Does peripheral knowledge complement control? An empirical test in technology outsourcing alliances", Strategic Management Journal, Vol. 28, pp. 623-634.

[45] Seo, Y-W., Han, H. S. and Lee, J. N. (2005), "A Relationship Perspective to Investigate the Effect of Human Resource Capability on Information System Outsourcing Success", Research and Practice in Human Resource Management, Vol. $13, \mathrm{~N}^{\circ} 2$, pp. 1-15.

[46] Gottschalk, P. (2006), "Research propositions for knowledge management systems supporting IT outsourcing relationships", Journal of Computer Information Systems, Vol. 46, N³, pp. 110-116.

[47] Haines, M. N. and Goodhue, D. L. (2003), "Implementation Partner Involvement and Knowledge Transfer in the Context of ERP Implementations", International Journal of HumanComputer Interaction, Vol. 16, $\mathrm{N}^{\circ} 1,23$ pages.

[48] Lee, J. N., Han, H. S., Lee, J. and Seo, Y. W. (2009), "The Fit between Client IT Capability and Vendor Competence and Its Impact on Outsourcing Success", AMCIS Proceedings, paper 644.

[49] Willcocks, L. and Kern, T. (1998), "IT Outsourcing As Strategic Partnering: The Case Of The Inland Revenue", European Journal Of Information Systems, Vol. 7, pp. 29-45.

[50] Khan, S. U., Niazi, M. and Ahmad, R. (2011), "Factors influencing clients in the selection of offshore software outsourcing vendors: An exploratory study using a systematic literature review", Journal of Systems and Software, Vol. 84, n², pp. 686-699. 
[51] Jahner, S., Böhmann, T. and Krcmar, H. (2006), "Relationship Archetypes in Information Systems Outsourcing Arrangements: An Exploratory Analysis", Proceedings of the Twelfth Americas Conference on Information Systems, Acapulco, Mexico.

[52] Sharma, R., Apoorva, SR., Madireddy, V. and Jain, V. (2008), "Best Practices for Communication between Client and Vendor in IT Outsourcing Projects", Journal of Information, Information Technology and Organizations, Vol. 3, pp. 61-93.

[53] Al-Salti, Z., Hackney, R. and Özkan, S. (2010), "Factors impacting knowledge transfer success in Information Systems Outsourcing", European, Mediterranean \& Middle Eastern Conference on Information Systems, (EMCIS2010), Abu Dhabi, UAE.

[54] Su, N., Levina, N. and Ross, J. W. (2016), "The Long-Tail strategy for IT Outsourcing", MIT Sloan Management Review, Vol. 57, N², pp. 80-90.

[55] Lu, Y. (2006), "IT capability, uncertainty and organizational performance: development of measures and empirical examination", Thèse de doctorat en Sciences de Management, The University of Wisconsin-Milwaukee.

[56] Mohr, J. and Spekman, R. (1994), "Characteristics of Partnership Success: Partnership Attributes, Communication Behavior and Conflict Resolution Techniques", Strategic Management Journal, Vol. 15, n², pp. 165-152.

[57] Chang, K. C., Sheu, T. S., Klein, G. and Jiang, J. J. (2010), "User commitment and collaboration: Motivational antecedents and project performance", Information and Software Technology, Vol. 52, pp. 672-679.

[58] Tenenhaus, M., Vinzi, V. E., Chatelin, Y-M. and Lauro, C. (2005), "PLS path modeling", Computational Statistics \& Data Analysis, Vol. 48, N¹, pp. 159-205.
[59] Fornell, C. D. and Larcker, F. (1981), "Evaluating structural equation models with unobservable variables and measurement errors", Journal of Marketing Research, Vol. 18, $\mathrm{N}^{\circ} 1$, pp. 39-50.

[60] Fernandes, V. (2012), "En quoi l'approche PLS est-elle une méthode a (re)- découvrir pour les chercheurs en management ?", Management, Vol. 15, Nº1, pp. 101-123.

[61] Hair, J. F., Hult, G. T. M., Ringle, C. M. and Sarstedt, M. (2014), A primer on Partial Least Squares structural equation modeling (PLS-SEM), Sage Publications.

[62] Bharadwaj, S. S., Saxena, K. and Halemane, M. D. (2010), "Building a successful relationship in business process outsourcing: An exploratory study", European Journal of Information Systems, Vol. 19, pp. 168-180.

[63] Lacity, M. C., Khan, S., Yan, A., and Willcocks, L. P. (2010), "A Review of the IT Outsourcing Empirical Literature and Future Research Directions", Journal of Information Technology, Vol. 24, Nº4, pp. 395-433.

[64] Alexandrova, M. (2012), "IT outsourcing partnerships: empirical research on key success factors in Bulgarian organizations", Management, Vol. 17, pp. 31-50.

[65] Ray, G., Barney, J. B. and Muhanna, W. A. (2004), "Capabilities, business processes, and competitive advantage: Choosing the dependent variable in empirical tests of the resources-based view", Strategic Management Journal, Vol. 25, N 10 , pp. 23-37.

[66] Sharma, R., Apoorva, SR., Madireddy, V. and Jain, V. (2008), "Best Practices for Communication between Client and Vendor in IT Outsourcing Projects", Journal of Information, Information Technology and Organizations, Vol. 3, pp. 61-93. 